\title{
A Wave Among Waves: Katherine Anne Porter's Near-Death Experience
}

\author{
Steve Straight \\ Department of English \\ University of Connecticut
}

\begin{abstract}
This article shows that the main vision in Katherine Anne Porter's 1938 story "Pale Horse, Pale Rider," based largely on her nearly fatal bout with influenza during the epidemic of 1918 , is a deep near-death experience (NDE) of the type first described by Raymond Moody (1975). Biographical sources and interviews with Porter demonstrate this as well as the NDE's physical and psychological effects on her. The story's vision of paradise is quoted and analyzed as an NDE. Two critical studies of the story (Youngblood, 1959/1960; Givner, 1982) are discussed briefly.
\end{abstract}

\section{INTRODUCTION}

Raymond Moody (1977) predicted in Reflections on Life After Life that the relatively small collection of near-death experiences (NDEs) he had found was only the beginning. He said researchers and scholars should be able to find all the cases they wanted. The work of Kenneth Ring (1980) and Michael Sabom (1982), especially, proved him right. And in 1982 George Gallup, Jr. wrote that the results of his poll of 1,500 adult Americans showed that one in twenty, or eight million adults in the United States, have had an NDE. If NDEs are that common, we might expect to find that some of those who have had an NDE were or are well known. In this article I will show that a famous and very gifted writer of this century, Katherine Anne Porter, had a deep near-death experience in 1918 and later described it in what many critics argue is her best work of fiction, "Pale Horse, Pale Rider" (1938/1979).

Porter was born in 1890 and lived until 1980. In a tumultuous life she lived in Texas, New Orleans, Denver, New York City, Mexico City, Paris, southern California, and Washington D.C. She is probably best known to the public for her novel, Ship of Fools (1962), later made into a movie. Even more than the novel, critics have pointed to her short story collections, Flowering Judas and Other Stories (1940/1979), The Leaning Tower and Other Stories (1944/1979), and Pale Horse, Pale Rider (1949/1979), ${ }^{1}$ as evidence of her great

$$
\begin{gathered}
\text { Anabiosis - The Journal for Near-Death } \\
\text { Studies, Fall 1984, Vol. 4, No. } 2
\end{gathered}
$$


talent. Robert Penn Warren (1951) wrote, "many of her stories are unsurpassed in modern fiction, and some are not often equaled" (pp. 136-137). He ranked her as a short story writer with James Joyce and Ernest Hemingway.

\section{FICTION AS AUTOBIOGRAPHY}

"Pale Horse, Pale Rider," a long story or a short novel, centers on the experiences of a young newspaper reporter in Denver near the end of World War I. The story is one of what are known as "the Miranda stories," chronicling the life of Miranda Gay. There is much evidence that Miranda's close brush with death in "Pale Horse, Pale Rider" is based very closely on the experience of Porter, who was a young reporter in Denver (for the Rocky Mountain News) in 1918.

In 1940 Porter told Robert Van Gelder, interviewing her for the New York Times Book Review, that the story was an attempt to record her experience of the moment of death. In 1956 she confirmed that in an interview in the Denver Post (Hendrick, 1965).2 And in 1963 she described the experience briefly in a Paris Review interview (Thompson, 1963). The most complete description of the circumstances causing her experience is found in Joan Givner's Katherine Anne Porter: A Life (1982):

[Porter] contracted influenza, and her case coincided exactly with the epidemic's rise and fall in Denver....

All accounts of the subsequent events coincide. By the time she was admitted to a hospital there seemed little hope that she could survive; she ran a fever of 105 for nine days ... . The Rocky Mountain News set up the obituary and the Porter family made arrangements for disposal of the body. ... One Sunday afternoon she was left behind screens to die .... At the same time a group of young interns in white coats looked at Porter as she lay dying in the corridor of the crowded hospital. They decided to give her an experimental shot of strychnine. Miraculously, it worked, and she began to fight her way back to life. (pp. 125-126)

Porter often let stories form in her mind for years before going to the typewriter, and she published little for one who lived so long. She did not attempt to write about her Denver experience until the 1930s. Even then she had difficulty with it at first, putting it aside from 1932 to 1936 (Givner, 1982). A lifelong friend of Porter's, Glenway Wescott, described in his Images of Truth (1939) a discussion with her in 1936: 
It pleases me to recall a conversation that I had with Katherine Anne while she was writing "Pale Horse, Pale Rider" and was having trouble with a passage in it toward the end in which Miranda, desperately ill, almost dead, was to see heaven. She told me that she herself, at the end of World War I, had experienced this part of what she had created this heroine to experience and to make manifest; and because, no doubt, it really was heaven, she found herself unable to re-see it with her lively, healthy eyes.

.. I I proposed to my dear friend and rival, "Why not at that point just write a page about your inability to recede, your impotence to write? Eternal curtain, blinding effulgence! Let each one of your readers fill in the kind of heaven that his particular life has prepared him to go to, when his turn comes.

"What else is heaven, anyway?" I went on, where angels fear to tread. "What can it be, empirically, but the indescribable; the defeat of literature, the end of empiricism?"

To my amusement and perhaps regret, mingled with a little vanity, Katherine Anne did not take to this suggestion. She let "Pale Horse" go for another year, and turned to other work .... (p. 37)

When she returned to the story, however, she seemed fired with one of her moments of rapid composition. As she told Van Gelder (1940), "It was necessary for me to return to Baton Rouge [in 1937]. I took a room in New Orleans on a Monday and finished ["Pale Horse, Pale Rider"] on the next Monday" (p. 20). The story runs about 23,000 words, and Porter considered it her best work (Nance, 1963).

\section{DREAMS AND VISIONS IN THE STORY}

"Pale Horse, Pale Rider" is a love story about Miranda, 24,3 and Adam Barclay, also 24 and a second lieutenant in an engineer corps. (There was a young lieutenant Porter knew in Denver, but there are conflicting reports from Porter herself how well she knew him [Givner, 1982] .) Miranda reviews plays for the Blue Mountain News and spends all her free time with Adam, dancing or talking. Adam is soon to be shipped overseas, and Miranda worries dreadfully that he will be killed.

The story is a masterpiece of style, weaving the day-to-day events of Miranda's life with a series of her dreams and then the near-death vision. It opens with a dream, in fact, that Miranda has of her childhood home. She dreams she rides her horse, Graylie, in a race against Death (the Pale Rider), who is a "lankish green stranger I remembered hanging about the place, welcomed by my grandfather, my great-aunt, my five times removed cousin, my decrepit hound 
and my silver kitten" (1938/1979, pp. 269-270). When she recognizes that he is Death, "she pulled Graylie up, rose in her stirrups and shouted, I'm not going with you this time-ride on! Without pausing or turning his head the stranger rode on" (p. 270). Suddenly we are in the newsroom, where Miranda is being pestered by Lusk Committeemen demanding she buy a Liberty Bond she knows she can't afford. The war encroaches on all sides.

The next night she goes to the theater to review a show and feels very weak and tired. She blames it on long hours and not eating right, but she knows it is serious: "She thought, This is the beginning of the end of something. Something terrible is going to happen to me. I chan't need bread and butter where I'm going" (p. 290). A little while later:

[She] closed her eyes and faced for one instant that was a lifetime the certain, the overwhelming and awful knowledge that there was nothing at all ahead for Adam and for her. Nothing. She opened her eyes and held her hands together palms up, gazing at them and trying to understand oblivion. (p. 291)

She manages to go dancing with Adam that night, but the next day she has contracted influenza and misses work.

Adam comes to nurse her and tries to find her a hospital bed, but none is available. Her fever increases. She has an awful nightmare of a jungle, a "writhing terribly alive and secret place of death" (p. 299), wakes, and then manages to swallow some medicine and food. She feels a little better, and she and Adam sing the old spiritual "Pale Horse, Pale Rider" ("done taken my lover away"). Then:

Miranda sighed, and lay back on the pillow and thought, I must give up, I can't hold out any longer. There was only that pain, only that room, and only Adam. There were no longer any multiple planes of living, no tough filaments of memory and hope pulling taut backwards and forwards holding her upright between them. There was only this one moment and it was a dream of time, and Adam's face, very near hers, eyes still and intent, was a shadow, and there was to be nothing more.... (p. 304)

Adam tells her to sleep, and she dreams in a kind of half-sleep of Adam dying and herself living:

Almost with no warning at all, she floated into the darkness, holding his hand, in a sleep that was not sleep but clear evening light in a small green wood, an angry dangerous wood full of inhuman concealed voices singing sharply like the whine of arrows and she saw Adam transfixed by a flight 
of these singing arrows that struck him in the heart and passed shrilly cutting their path through the leaves. Adam fell straight back before her eyes, and rose again unwounded and alive; another flight of arrows loosed from the invisible bow struck him again and he fell, and yet he was there before her untouched in a perpetual death and resurrection. She threw herself before him, angrily and selfishly she interposed between him and the track of the arrow, crying, No, no, like a child cheated in a game, It's my turn now, why must you always be the one to die? and the arrows struck her cleanly through the heart and through his body and he lay dead, and she still lived.... (pp. 304-305)

Adam leaves her briefly to get more food. While he is gone she is taken to a hospital. She knows many of the people with influenza die, and her mind swirls with thoughts of what death is like:

The road to death is a long march beset with all evils, and the heart fails little by little at cach new terror, the bones rebel at each step, the mind sets up its own bitter resistance and to what end? The barriers sink one by one, and no covering of the eyes shuts out the landscape of disaster, nor the sight of crimes committed there. (p. 309)

A nightmare follows of her doctor, who happens to have a German name, murdering a baby. She wakes "howling" and realizes that she has been screaming at him to his face. She tries to apologize, but

the wrong she had done followed her and haunted her dream: this wrong took vague shapes of horror she could not resist or name, though her heart cringed at sight of them. Her mind, split in two, acknowledged and denied what she saw in the one instant, for across an abyss of complaining darkness her reasoning coherent self watched the strange frenzy of the other coldly, reluctant to admit the truth of its visions, its tenacious remorses and despairs. (pp. 309-310)

Her fears reach their peak now, as she tries to envision her fate:

Oblivion, thought Miranda, her mind feeling among her memories of words she had been taught to describe the unseen, the unknowable, is a whirlpool of gray water turning upon itself for all eternity . . . eternity is perhaps more than the distance to the farthest star. She lay on a narrow ledge over a pit that she knew to be bottomless, though she could not comprehend it; the ledge was her childhood dream of danger, and she strained back against a reassuring wall of granitc at her shoulders, staring into the pit, thinking, There it is, there it is at last, it is very simple; and soft carefully shaped words like oblivion and eternity are curtains hung before nothing at all. I shall not know when it happens, I shall not feel or remember, why can't I consent now, I am lost, there is no hope for me. Look, she told herself, there it is, that is death and there is nothing to fear. 
But she could not consent, still shrinking stiffly against the granite wall that was her childhood dream of safety, breathing slowly for fear of squandering breath, saying desperately, Look, don't be afraid, it is nothing, it is only eternity.

Granite walls, whirlpools, stars are things. None of them is death, nor the image of it. Death is death, said Miranda, and for the dead it has no attributes. (p. 310)

In the next line her NDE proper begins. As it turns out, of course, death isn't any of the horrible things she imagined:

Silenced she sank casily through deeps under deeps of darkness until she lay like a stonc at the farthest bottom of life, knowing herself to be blind, dcaf, speechless, no longer aware of the members of her own body, entircly withdrawn from all human concerns, yet alive with a peculiar lucidity and coherence; all notions of the mind, the reasonable inquiries of doubt, all ties of blood and the desires of the heart, dissolved and fell away from her, and there remained of her only a minute fiercely burning particle of being that knew itself alone, that relied upon nothing beyond itsclf for its strength; not susceptible to any appeal or inducement, being itsclf composed cntircly of one single motive, the stubborn will to live. This ficry motionless particle set itsclf unaided to resist destruction, to survive and to be in its own madncss of being, motiveless and planless beyond that one essential $\mathrm{cnd}$. Trust me, the hard unwinking angry point of light said. Trust me. I stay.

At once it grew, flattened, thinned to a fine radiance, spread like a great fan and curved out into a rainbow through which Miranda, enchanted, altogether believing, looked upon a deep clear landscape of sea and sand, of soft meadow and sky, freshly washed and glistening with transparencies of blue. Why, of course, of course, said Miranda, without surprise but with screnc rapture as if some promisc made to her had been kept long after she ccased to hope for it. She rose from her narrow ledge and ran lightly through the tall portals of the great bow that arched in its splendor over the burning blue of the sea and the cool green of the meadow on either hand.

The small waves rolled in and over unhurriedly, lapped upon the sand in silence and retreated; the grasses flurried before a breeze that made no sound. Moving towards her leisurely as clouds through the shimmering air came a great company of human beings, and Miranda saw in an amazement of joy that they were all the living she had known. Their faces were transfigured, each in its own beauty, beyond what she remembered of them, their cyes were clear and untroubled as good weather, and they cast no shadows. They were pure identities and she knew them every one without calling their names or remembering what relation she bore to them. They surrounded her smoothly on silent feet, then turned their entranced faces again towards the sea, and she moved among them easily as a wave among waves. The drifting circle widened, separated, and each figure was alone but not solitary; Miranda, alone too, questioning nothing, desiring nothing, in the quietude of her ecstasy, stayed where she was, 
eyes fixed on the overwhelming deep sky where it was always morning. (pp. 310-311)

That is the climax of her near-death vision. Immediately following it, as in many NDEs, comes her decision to return:

Lying at ease, arms under her head, in the prodigal warmth which flowed evenly from sea and sky and meadow, within touch but not touching the serenely smiling familiar beings about her, Miranda felt without warning a vague tremor of apprehension, some small flick of distrust in her joy; a thin frost touched the edges of this confident tranquility; something, somebody, was missing, she had lost something, she had left something valuable in another country, oh, what could it be? There are no trees, no trees here, she said in fright, I have left something unfinished. A thought struggled at the back of her mind, came clearly as a voice in her ear. Where are the dead? We have forgotten the dead, oh, the dead, where are they? At once as if a curtain had fallen, the bright landscape faded, she was alone in a strange stony place of bitter cold, picking her way along a steep path of slippery snow, calling out, Oh, I must go back! But in what direction? (pp. 311-312)

Like many near-death experiencers, Miranda decides she must return because of unfinished business in the living world. What triggers her decision is perhaps the most confusing line in the story: "We have forgotten the dead, oh the dead, where are they?" Most NDErs who see people they have known see those who have died before them. We might have expected Miranda to see her grandfather, her great aunt, or one of the others that appeared in the initial dream of racing Death. Instead she saw "all the living she had known."

To most readers of this journal, I imagine, Miranda's journey so far demonstrates many of the elements of a deep NDE. But since the rest of the story contains other familiar sensations, I will not discuss the NDE just yet. After the last line I quoted, Miranda is suddenly back in the world of the living:

Pain returned, a terrible compelling pain running through her veins like heavy fire, the stench of corruption filled her nostrils, the sweetish sickening smell of rotting flesh and pus; she opened her eyes and saw pale light through a coarse white cloth over her face, knew that the smell of death was in her own body, and struggled to lift her hand. The cloth was drawn away; she saw Miss Tanner filling a hypodermic needle in her methodical expert way, and heard Dr. Hildesheim saying, "I think that will do the trick. Try another." Miss Tanner plucked firmly at Miranda's arm near the shoulder, and the unbelievable current of agony ran burning through her veins again. She struggled to cry out, saying, Let me go, let me go; 
but heard only incoherent sounds of animal suffering. She saw doctor and nurse glance at each other with the glance of initiates at a mystery, nodding in silence, their eyes alive with knowledgeable pride. (p. 312)

Miranda decides she must return, but once back she is not pleased with life. Her mind fights each harsh sensation, and there are many:

Bells screamed all off key, wrangling together as they collided in mid air, horns and whistles mingled shrilly with cries of human distress; sulphur colored light exploded through the black window pane and flashed away in darkness. Miranda waking from a dreamless sleep asked without expecting an answer, "What is happening?" for there was a bustle of voices and footsteps in the corridor, and a sharpness in the air; the far clamor went on, a furious exasperated shrieking like a mob in revolt. (p. 312)

The noises prove to be a crowd outside celebrating the end of the war, but it is to Miranda a "bitter world where the sound of rejoicing was a clamor of pain."

"Please open the window, please," she says to the nurse, "I smell death in here" (p. 313).

Miranda's bitterness continues as she can't help comparing the two worlds she has experienced:

Now if real daylight such as I remember having seen in this world would only come again, but it is always twilight or just before morning, a promise of day that is never kept. What has become of the sun? That was the longest night and yet it will not end and let the day comc. Shall I ever see light again?

Sitting in a long chair, near a window, it was in itself a melancholy wonder to see the colorless sunlight slanting on the snow, under a sky drained of its blue. "Can this be my face?" Miranda asked her mirror. "Are these my own hands?" she asked Miss Tanner, holding them up to show the yellow tint like melted wax glimmering between the closed fingers. The body is a curious monster, no place to live in, how could anyone feel at home there? Is it possible I can evir accustom myself to this place? she asked herself. The human faces around her seemed dull and tired, with no radiance of skin and eyes as Miranda remembered radiance; the once white walls of her room were now a soiled gray. Preathing slowly, falling asleep and waking again, feeling the splash of water on her flesh, taking food, talking in bare phrases with Dr. Hildesheim and Miss Tanner, Miranda looked about her with the covertly hostile eyes of an alien who does not like the country in which he finds himsclf, does not understand the language nor wish to learn it, does not mean to live there and yet is helpless, unable to leave it at his will. (p. 313)

Her nurse asks her to look, just look at the sunshine. Miranda tries to be helpful, giving the answer Miss Tanner wants to hear: 


\begin{abstract}
"It's beautiful," Miranda would answer, even turning her head to look, thanking Miss Tanner for her goodness about the weather, "beautiful, I always loved it." And I might love it again if I saw it, she thought, but truth was, she could not see it. There was no light, there might never be light again, compared as it must always be with the light she had seen beside the blue sea that lay so tranquilly along the shore of her paradise. That was a child's dream of the heavenly meadow, the vision of repose that comes to a tired body in sleep, she thought, but $I$ have seen it when I did not know it was a dream. Closing her eyes she would rest for a moment remembering that bill which had repaid all the pain of the journey to reach it; opening them again she saw with a new anguish the dull world to which she was condemned, where the light seemed filmed over with cobwebs, all the bright surfaces corroded, the sharp planes melted and formless, all objects and being meaningless, ah, dead and withered things that believed themselves alive!

At night, after the long effort of lying in her chair, in her extremity of grief for what she had so briefly won, she folded her painful body together and wept silently, shamelessly, in pity for herself and her lost rapture. (p. 314)
\end{abstract}

Friends come, and she tells them what they expect, too:

For ten minutes Miranda smiled and told them how gay and what a pleasant surprise it was to find herself alive. For it will not do to betray the conspiracy and tamper with the courage of the living; there is nothing better than to be alive, everyone has agreed on that; it is past argument, and who attempts to deny it is justly outlawed. (p. 315)

Her doctor and nurse urge her to read her mail, and all the letters gaily congratulate her on cheating death. One letter among them reports that Adam, her lover, has died of influenza in the camp hospital a month earlier. He had no doubt contracted it while nursing her. Their separation by death is just as she had foreseen it in her feverish dream of the singing arrows.

Miranda decides that if she must be alive again, she'll do it with style. She orders a "walking stick of silvery wood with a silver knob." And she says to herself, "Lazarus, come forth. Not unless you bring me my top hat and stick. Stay where you are then, you snob. Not at all. I'm coming forth" (p. 316). As she readies herself for the world,

Miranda wondered again at the time and trouble the living took to be helpful to the dead. But not quite dead now, she reassured herself, one foot in either world now; soon I shall cross back and be at home again. The light will seem real and I shall be glad when I hear that someone I know has escaped from death. (pp. 316-317) 
She thinks of Adam, and many critics have said that the way she does indicates he is why she returned: "Adam, she said, now you need not die again, but still I wish you were here; I wish you had come back, what do you think I came back for, Adam, to be deceived like this?" (p. 317) She wishes he had lived and then calls herself selfish and unreasonable for wishing it.

Finally, in the last paragraph of the story, she summarizes what her life is to be like, and with heavy irony:

No more war, no more plague, only the dazed silence that follows the ceasing of the heavy guns; noiseless houses with the shades drawn, empty streets, the dead cold light of tomorrow. Now there would be time for every thing. (p. 317)

On the audiocassette Porter (1952) recorded of "Pale Horse, Pale Rider," she reads very quickly, breathlessly, and she emphasizes the last syllable, -thing, in the last line. I also like the meaning one gets from putting the accent on time in that line, since she has returned from timeless ecstasy to the plodding linear world.

\section{ANALYSIS OF THE NDE}

If Porter's description of Miranda's experience near death was largely autobiographical, and there seems no doubt it was, her neardeath experience in 1918 at the age of 28 was profound. Using Ring's (1980) Weighted Core Experience Index (WCEI), we have a reasonable measure of how deep it was. On a scale of $0-29$, with a score of 10 or more indicating a deep experience, Porter's NDE. measures about a 23 .

To obtain a perfectly accurate score, of course, would have required interviewing Porter. Her description in "Pale Horse, Pale Rider," though, is so rich that it is fairly easy to use the WCEI. We can, I think, assign her 1 point for the subjective sense of being dead, 4 points for a very strong sense of peace or pleasantness, 4 points for a clear sense of being out of her body, 4 points for movement through a dark region, 3 points for encountering visible "spirits" (although perhaps not another 3 for "encountering a presence/ hearing a voice"), 2 points for seeing a light, 1 point for seeing beautiful colors, and 4 points for entering into the light (in the clear sense of entering a world of beauty through the light). Another 3 points for "taking stock of one's life" were not awarded. All points awarded were the maximum for that category. 
In terms of Ring's (1980) stages of the NDE, Porter had all five. Ten percent of the "core experiencers" in Ring's study reached the fifth stage (entering the light).

\section{EFFECTS OF THE NDE ON PORTER}

Any questions we might have about exactly how significant Porter's NDE was in her life are answered in her interviews and biographies. The effects ranged from the expected physical ones of nearly dying to strong emotional ones that profoundly affected her life and work. In addition one anecdote I will mention at the end of this section indicates she may have gained some psychical powers.

Several biographers have described the physical effects of Porter's 1918 illness. In the 1956 Denver Post interview (Hendrick, 1965), Porter herself said:

"I knew I was dying. I felt a strange state of . . . euphoria . . . . But I didn't die. I mustered the will to live. My hair turned white and then fell out. The first time I tried to rise to a sitting position I fell and broke an arm. I had phlebitis in one leg and they said I'd never walk again. But I was determined to walk and live again, and in six months I was walking and my hair was grown back." (p. 76)

In the same interview Porter mentioned the effect on her fear of death. The effect was the most common of all among NDErs: "It seems to me true that I died then, I died once, and I have never feared death since" (Hendrick, 1965, p. 76).

The emotional effects on Porter were strong but they were confuised. She had the same jaundiced view of the world she gave Miranda, but she herself managed to rally from it:

"I had seen my heavenly vision and the world was pretty dull after that. My mood for several years thereafter was that it was not a world worth living in. And yet one has faith, one has the inner core of strength that comes from somewhere, probably inherited from someone. Throughout my life there have been times during the day when I have both an intense wish to die and later an eagerness that can't wait to see the next day. In fact, if I hadn't been tough as an alley cat, I wouldn't be here today." (Lopez, 1981, p. 48)

That interviewer, Enrique Hank Lopez, also commented that she "became somewhat of a recluse, often lunching alone and going straight home after work" (p. 48), still at the Rocky Mountain News. He wrote that some of her articles in the News "[reflected] her pro- 
found disenchantment with most of her fellow human beings" (p. 48).

She was changed, and there are indications she had to see that herself before she could move on to her new life. In the Paris Review interview (Thompson, 1963) she discussed her childhood desire to become a writer. The interviewer, Barbara Thompson, then asked, "But weren't there certain specific events that crystallized that desire for you-something comparable to the experience of Miranda in "Pale Horse, Pale Rider"?" (p. 96). Porter's response shows both the power and the variety of effects her NDE had:

Porter: Yes, that was the plague of influenza, at the end of the first World War, in which I almost died. It just simply divided my life, cut across it like that. So that everything before that was just getting ready, and after that I was in some strange way altered, ready. It took me a long time to go out and live in the world again. I was really "alienated," in the pure sense. It was, I think, the fact that I really had participated in death, that I knew what death was, and had almost experienced it. I had what the Christians call the "beatific vision," and the Greeks called the "happy day," the happy vision just before death. 4 Now if you have had that, and survived it, come back from it, you are no longer like other people, and there's no use deceiving yourself that you are. But you see, I did: I made the mistake of thinking I was quite like anybody else, of trying to live like other people. It took me a long time to realize that that simply wasn't true, that I had my own needs and that I had to live like me.

Thompson: And that freed you?

Porter: I just got up and bolted. I went running off on that wild escapade to Mexico, where I attended, you might say, and assisted at, in my own modest way, a revolution. (pp. 96-97)

Porter went to live in Greenwich Village first (Givner, 1982), so her response indicates her new freedom came sumetime before she went to Mexico during the Obregon Revolution of 1921.

Other, more subtle changes in Porter are indicated elsewhere, I think. She said to Thompson (1963), "I have always lived in my immediate circumstances, from day to day" (p. 109). This here-andnow attitude is typical of NDErs. And the following fascinating comment from one of Porter's friends says much the same about her ability to stay in the present: 
"She doesn't wait for death to effect transmigration," one of her friends said recently. "Every now and then she stops being what she is and becomes something else. In some secluded corner of the world, she spins a cocoon, and presently comes out more brilliantly colored, with longer, swifter wings. She leaves her old life there in a tree, dry and forgotten and dead, something she has put forever behind her." (Crume, 1940, p. 214)

In summary, then, the effects on Porter were profound and long lasting, exactly what we would expect from such a deep NDE.

I mentioned earlier that Porter had a memorable psychic experience shortly after her NDE. I don't want to make too much of this, but there is evidence (Kohr, 1983) that NDErs tend to be more attuned to such happenings. The experience has to do with her sister's daughter, with whom Porter was extremely close. After Porter had regained her strength and had written many reviews for the News,

one summer night in July [1919] she was suddenly overcome with a growing apprehension and premonition of disaster which grew to a state of panic. Without understanding why, she fell about the floor in paroxysms of grief and terror and finally heard herself say that she must go home. Having made that decision she set her alarm clock so that she would wake early and, exhausted by her frenzy, fell asleep. It was noon when she woke, having overslept the alarm clock, and she found a telegram pushed under her door which told her that her little niece, Mary Alice, had died of spinal meningitis. Later she received a letter, unaccountably delayed, which told her of the child's illness. (Givner, 1982, p. 137)

\section{THE CRITICS}

Most critics of "Pale Horse, Pale Rider" recognize it as a great story. Many acknowledge the autobiographical root and most then argue over the story's tone, symbolism, and characterization. I will not pursue such arguments here, but $I$ think any critic who knew the near-death literature might see the story afresh. I will restrict my comments to two critics, Sarah Youngblood (1959/1960) and Givner (1982).

Youngblood's study is, I believe, the most perceptive and accurate of the criticism. It does not appear that she knew about Porter's 1918 experience. At least her criticism is based strictly on the story itself. Even so, she discusses the near-death vision without reducing it to merely a death wish or merely a dream, as other critics have: 
The distinctive features of the paradise are silence, radiance, joy. In its features this paradise suggests the traditional mystical experience, and Miranda's later revulsion to the colorless sunlight and pain of the actual world suggests the disillusioned "stage of experience" which a mystic undergoes after his return to the world of a tangible reality. This suggestion of the mystical experience is strengthened by the variety of religious imagery elsewhere in the story, and by the presence within the paradise of the rainbow-symbol. (1959/1960, p. 351)

Once Miranda is back from the paradise,

there is also here the implication that all of the real world is the world of the "dead." The imagery of the world she returns to is dominantly that of violent noise, and gray colorless light ... . To Miranda now "the body is a curious monster, no place to live in," as the flesh is alien to the returned mystic, and she is like "an alien who does not like the country in which he finds himself, does not understand the language." ... The irony of Miranda's situation is overwhelming: "the humane conviction and custom of society" insists that life is best, and will force her to pay twice for the gift of death, making her endure again at some future date the painful journey to the blue sea and tranquil meadow of her paradise. It is a part of this irony that Adam, for whom she returned, is already dead. (1959/) 1960, p. 351)

Apparently thinking the story was just made up, Youngblood still recognizes both how profound and how "real" its main vision is.

Concerning the "hard unwinking angry point of light" that becomes the preternatural landscape, Youngblood is again, I think, on the mark: "It is ironic that the 'angry point of light' symbolizing her will to live is the ultimate source of the radiance which spreads and curves into the rainbow of her paradise" (1959/1960, p. 350).

Givner's (1982) criticism, on the other hand, seems inadequate. In her 512-page biography she is very critical of Porter's tendency to embellish her life history, much the way Samuel Clemens became Mark Twain, storyteller, over the years. She gives many new details on Porter's 1918 experience. Yet in a seemingly thorough book published seven years after Moody's Life After Life (1975), she is the one guilty of stretching the facts and missing the point.

She quotes Porter's (1977) essay on the execution of Sacco and Vanzetti (which took place in 1927) as follows:

For an endless dreary time we had stood there massed in a measureless darkness, waiting, watching the light in the tower of the prison. At midnight, this light winked off, winked on and off again, and my blood chills remembering it even now-I do not remember how often, but we were 
told that the extinction of this light corresponded to the number of charges of electricity sent through the bodies of Sacco and Vanzetti. (1982, p. 192)

Somehow she equates the winking tower light of the Boston prison with the unwinking point of light in Porter's story written ten years later. Recalling Wescott's (1939) comments on Porter's struggle to write the ending of "Pale Horse, Pale Rider," she pronounces:

Eventually Porter solved the problem of describing Miranda's death and return to life. She took the little flickering point of light, so indelibly fixed in her imagination at the Charlestown prison, and used it as the image of Miranda's facing life: "This fiery motionless particle set itself unaided to resist destruction, to survive and to be in its own madness of being, motiveless and planless beyond that one essential end. Trust me, the hard unwinking angry points [sic] of light said. Trust me. I stay." (1982, p. 192)

This seems quite farfetched to me.

\section{CONCLUSION}

I do not pretend to be able to show the influences of Katherine Anne Porter's NDE on her body of work or on all the events of her life. Porter's description of her NDE in "Pale Horse, Pale Rider," however, is the deepest and most beautiful I have found in fiction. Her ability to put the ineffable into words is, I think, wonderfully described in Robert Penn Warren's (1951) analysis of her greatness and its source:

Few [writers] have been able to achieve stories of deep philosophic urgency in the narrow space, and fewer still have been able to achieve the kind of thematic integration of a body of stories, the mark of the masters, the thing that makes us think first of the central significance of a writer rather than of some incidental and individual triumph. For Miss Porter's bright indicative poetry is, at long last, a literally metaphysical poetry, too. The luminosity is from inward. (pp. 155-156)

\section{NOTES}

1. The Collected Stories (see References), published in 1979, contains all the stories in the three collections mentioned. "Pale Horse, Pale Rider" was originally published in the Southern Review, 1938, 3 (Winter). 
2. George Hendrick's note gives the source as the Denver Post, March 22, 1956. Hendrick wrote that he was quoting Kathryn Adams Sexton, "Katherine Anne Porter's Years in Denver," unpublished M.A. thesis, University of Colorado, 1961, pp. 8485. All subsequent Hendrick quotations are from the same place.

3. For years Porter told people she was born in 1894 , which would have made her exactly Miranda's age.

4. Lopez's book contains an interesting detail about the name Miranda: "Though Shakespeare had used the name Miranda in the Latin sense, in which it means 'strange and wonderful,' Miss Porcer preferred its Spanish meaning-"the seeing one", (1981, p. 203).

\section{REFERENCES}

Crume, P. "Pale Horse, Pale Rider." Southwest Review, 1940, 25, 213-218.

Gallup, G., Jr. Adventures in Immortality. New York: McGrawHill, 1982.

Givner, J. Katherine Anne Porter: A Life. New York: Simon and Schuster, 1982.

Hendrick, G. Katherine Anne Porter. New York: Twayne, 1965. Kohr, R. L. Near-death experiences, altered states, and psi sensitivity. Anabiosis, 1983, 3, 157-176.

Lopez, E. H. Conversations with Katherine Anne Porter. Boston: Little, Brown, 1981.

Moody, R. A. Life After Life. Covington, GA: Mockingbird, 1975: Moody, R. A. Reflections on Life After Life. New York: Bantam, 1977.

Nance, W. L. Katherine Anne Porter \& the Art of Rejection. Chapel Hill, NC: University of North Carolina Press, 1963.

Porter, K. A. (speaker). "Pale Horse, Pale Rider" [audiocassette]. New York: Caedmon Records, 1952.

Porter, K. A. Ship of Fools. Boston: Atlantic-Little, Brown, 1962. Porter, K. A. The Collected Stories. New York: Harvest-Harcourt Brace Jovanovich, 1979.

Ring, K. Life at Death. New York: Coward, McCann and Geoghegan, 1980.

Sabom, M. Recollections of Death. New York: Harper \& Row, 1982.

Thompson, B. Katherine Anne Porter: an interview. Paris Review, $1963,29,95-114$. 
Van Gelder, R. Katherine Anne Porter at work. New York Times Book Review, 1940, April 14, p. 20.

Warren, R. P. Irony with a center: Katherine Anne Porter. In his Selected Essays. New York: Random House, 1951.

Westcott, G. Images of Truth. New York: Harper \& Row, 1939. Youngblood, S. Structure and imagery in Katherine Anne Porter's Pale Horse, Pale Rider. Modern Fiction Studies, 1959/1960, 5, 344-352.

Requests for reprints to:

Steve Straight

IANDS

Box U-20

University of Connecticut

Storrs, CT 06268 
